\title{
Parental role models and the decision to become self-employed: The moderating effect of personality
}

\author{
Simone Chlosta $\cdot$ Holger Patzelt $\cdot$ \\ Sabine B. Klein · Christian Dormann
}

Accepted: 25 January 2010/Published online: 6 March 2010

(C) The Author(s) 2010. This article is published with open access at Springerlink.com

\begin{abstract}
This paper uses social learning theory to examine the influence of parental role models in entrepreneurial families. We distinguish between paternal and maternal role models and investigate how their influence on offsprings' decision to become self-employed is moderated by personality, specifically the offsprings' openness. We use data on 461 alumni from eight German universities. Our results show not only that the presence of a parental role model increases the likelihood that individuals become self-employed, but that the influence of role
\end{abstract}

\section{S. Chlosta $(\bowtie)$}

European Business School, European Family Business Center, Rheingau Palais, Soehnleinstrasse 8/D, 65201

Wiesbaden, Germany

e-mail: simone.chlosta@ebs.de

H. Patzelt

Max-Planck-Institute of Economics, Kahlaische Strasse 10, 07745 Jena, Germany

e-mail: patzelt@econ.mpg.de

\section{S. B. Klein}

WHU Otto Beisheim School of Management, INTES Institute of Family Business, Burgplatz 2, 56179

Vallendar, Germany

e-mail: sabine.klein@whu.edu

\section{Dormann}

Department for Work, Organizational, and Economic Psychology, Johannes Gutenberg University Mainz, Wallstrasse 3, 55099 Mainz, Germany

e-mail: cdormann@uni-mainz.de models also depends on the individual's openness. We discuss the implications of our findings for research on entrepreneurial families, role models, and the psychology of the entrepreneur.

Keywords Role model · Self-employment · Personality · Openness · Moderator ·

Entrepreneurship

JEL Classifications $\quad \mathrm{C} 12 \cdot \mathrm{L} 26 \cdot \mathrm{M} 13 \cdot \mathrm{R} 11$

\section{Introduction}

Why individuals become self-employed has been a central question of entrepreneurship research since the very beginning of the field. This interest is due to the relevance of entrepreneurial activities to nearly all economies around the globe, and it explains why entrepreneurial families have been an important topic of study for both entrepreneurship and family business scholars.

We define entrepreneurial families as those with a heritage of entrepreneurship and business ownership. This includes at least one self-employed parent owning and managing a business within an entrepreneurial family. Growing up in an entrepreneurial family offers the opportunity to learn from the self-employed parent serving as a role model and getting a realistic job preview of self-employment. Two explanations from 
very different angles dominate the discussion on why an individual becomes self-employed: a personalitydriven explanation and a behavioral explanation. While the personality-driven explanation stresses that individuals with certain traits have a higher probability of becoming self-employed (Rauch and Frese 2007; Zhao and Seibert 2006; Barrick and Mount 1991), the behavioral explanation highlights the fact that individuals tend to learn from others who are role models for them (Mancuso 1974; Bandura 1986). Researchers have found that early exposure to parental role models in the family business will affect the children's attitude towards becoming self-employed themselves (Dyer et al. 1994; Carr and Sequeira 2007) and that growing up in a family with self-employed family members may lead to a general probusiness attitude of the children (Dunn and Holtz-Eakin 2000). Finally, children in an entrepreneurial family can benefit from being mentored by their parents and by accessing the business networks of their parents (Kim et al. 2006; White et al. 2007).

While the above-cited and other studies demonstrate that role models in entrepreneurial families are generally influential for the motivation of their offspring to become self-employed, this evidence has not always been unambiguous. For instance, some studies have found that parental role models do not stimulate individuals to become entrepreneurs (Kets de Vries 1977; Brenner et al. 1991; Kim et al. 2006; Ghazali et al. 1995), and in many entrepreneurial families children do not take over the businesses of their parents (Kepner 1983; Rodriguez et al. 1999). Thus, there appears to be considerable variance in the effect of parental role models on individuals' decisions to enter self-employment.

In this paper we provide an explanation, so far unexplored, for why parental role models in some entrepreneurial families stimulate self-employment among their offspring, while in other families they do not. We draw on social learning theory (Bandura 1986), which suggests that individuals learn by observing the actions of their parents and transferring these cues into "internal codes." These internal codes form a part of the offsprings' mental models and determine their decision policies (Bandura 1986; Rosenthal and Bandura 1978; Rotter et al. 1972; Bandura and Walters 1963), including their later occupational choice (Schulenberg et al. 1984; Scherer et al. 1989) and the decision to become self-employed (Schröder and Schmitt-Rodermund 2006).

However, we also know that personality plays a role in decision-making. In particular, openness appears to be a key personality trait in predicting self-employment decisions. Openness refers to the tendency to be creative, innovative, untraditional (Zhao and Seibert 2006), and free from conformity and security, that is, the willingness to change the status quo and experiment with new and different ideas (Roccas et al. 2002). As the effects of personality on self-employment decisions are mixed, we expect this relationship to be more complex. Therefore, we suggest a model consisting of openness in conjunction with role models to explain why some children follow their parents in becoming entrepreneurs while others do not. Furthermore, drawing on the literature on gender roles and gender stereotypes, we propose different effects for paternal and maternal role models. We test our hypotheses by using data on the careers and family backgrounds of 461 individuals in Germany.

Our study contributes to the entrepreneurship literature in several ways. First, the unique and most important contribution of our study is that we identify a contingency variable that moderates the effect of parental role models on individuals' decisions to become self-employed. Previous studies have shown that parents influence the self-employment decisions of their children (e.g., Scott and Twomey 1988; Birley 1989; Davidsson and Honig 2003; Wang and Wong 2004; Schmitt-Rodermund 2004), but these studies do not explain why some individuals follow parental role models while others do not. Second, the family business literature has investigated how characteristics of the parents (Dumas 1990; Stavrou 1999), their family business (e.g., Dunn and HoltzEakin 2000; Stavrou 1999), and family dynamics (e.g., Morris et al. 1997; Rodriguez et al. 1999) motivate individuals to take over family businesses, but it has neglected to show how the characteristics of family offspring strengthen or counteract that motivation. Our results suggest that the psychology of the individual plays a key role in the succession decision. Third, research on entrepreneurial parental role models has mostly investigated the effect of one parent, i.e., the father (e.g., De Witt and Van Winden 1989). We distinguish between paternal and maternal role models and show that their influence on the 
individuals' decisions to enter self-employment differs. Finally, a considerable body of literature has analyzed the role of personality in the decision to become self-employed (e.g., Rauch and Frese 2007; Zhao and Seibert 2006), but the results are mixed (Gartner 1988; Baum and Locke 2004). In contrast to these studies, we do not focus on the direct effects of personality on occupational decision-making, but rather use personality as a moderator to explain why some individuals act in accordance with entrepreneurial parental role models while others do not.

This article proceeds as follows. Next, we use social learning theory to predict self-employment by means of role model influences. We then discuss specific theoretical arguments for the moderating role of personality. In the subsequent sections, we describe our methodology, data, and results. Finally, we discuss our findings, highlight limitations, and draw conclusions.

\section{Literature review and hypothesis development}

\subsection{Parental role models and self-employment}

Of the many potential role models that influence an individual's social learning, parental role models are particularly relevant, since children are especially exposed to their parents' behaviors. Demonstrating something to someone through one's own choices in life has a very pragmatic influence, serving as an "orientation guide" and encouraging imitation (Schmitt-Rodermund and Vondracek 2002; Bandura 1986). Thus, the behavior that children observe and learn from their parents decisively affects their development. This kind of influence is rooted in sociological and psychological theories focusing on the socialization of children, including the withinfamily transmission of information, beliefs, and resources. These theories stress that social learning occurs within families as a means to assist children in adopting the social roles and behaviors that are necessary for them to participate in society (Brim 1968).

According to social learning theory, "of the numerous predictive cues that influence behavior at any given moment, none is more common or informative than the actions of others" (Bandura 1986, p. 206). By observing the behavior of others in their environments, individuals learn and acquire internal codes of behavior influencing their perceptions and actions. Learning from role models can lead individuals to initiate similar behaviors, strengthen or weaken their existing restraints against particular behaviors, or transmit new patterns of behavior. The stronger the effects of the role models on the observer, the more relevance and credibility these role models entail for the observer (Bandura 1986; Matthews and Moser 1996).

While the above arguments suggest that social learning theory is well suited to explain influences of parental role models on children's behavior, it is important to note that it is not the purpose of this paper to rigorously test this theory. That is, we use it as a tool to understand how parental role models influence individuals' career decisions, and this application of the theory is based on a number of assumptions. For example, we assume that children pay attention to their parents' behaviors and experiences, particularly since attention toward environmental stimuli (such as role models) is a prerequisite to reaction to these stimuli (Rensink 2000). Furthermore, our arguments are in line with research acknowledging that parents play an active role in influencing their children's behavior through both positive and negative feedback (Bandura 1986; Bandura and Walters 1963).

Research has demonstrated that parental work experiences have significant effects on children, and that children learn from their parents' experiences by internalizing them as norms of behavior (Menaghan and Parcel 1995). Social learning from parental role models influences children's later professional orientation (Bird 1993; Stavrou and Swiercz 1998; Korunka et al. 2003; Carr and Sequeira 2007), such as their potential interest to become entrepreneurs themselves (Birley 1989; Davidsson and Honig 2003; Wang and Wong 2004); for example, through early exposure to self-employment children receive an informal introduction to business methods from their parents, who transfer the knowledge they have acquired during their own self-employment experience (Dunn and Holtz-Eakin 2000; Mueller 2006).

Social learning while growing up in an entrepreneurial family can also lead children to develop certain values which are important antecedents of the decision to become self-employed; for example, 
work by Dunn and Holtz-Eakin (2000) suggests that children in entrepreneurial families acquire the need and desire to strive for independence from their parents, resulting in an enhanced tendency towards entering self-employment (e.g., Shane et al. 2003). While these and other studies (Scott and Twomey 1988; De Witt and Van Winden 1989; Wang and Wong 2004; Schmitt-Rodermund 2004) provide support for parental role models generally encouraging family offspring to become self-employed, it appears that paternal role models and maternal role models influence this decision to a different extent. First, same-sector effects (i.e., that children choose the same educational specialization as parents) appear to be somewhat stronger for fathers and sons, while no such same-sex influence is confirmed for mothers and daughters (Russel et al. 2003), suggesting that paternal role models play a more significant role in their children's occupational choice than do maternal role models. For example, in most Western countries, fathers are responsible for earning the living, are more career oriented, and are more interested in status attainment compared with mothers (Eddleston et al. 2006). Mothers (still) do have a choice between family and work: running the household and watching over the children, engaging in part-time employment (to add to the family's resources), or selecting (self-)employment following their own interests (or opportunity or motivation) rather than the family's need for further resources (Minniti et al. 2005). This suggests that offspring might experience their father's self-employment as "more intense" than their mother's, such that social learning is more strongly influenced by paternal than maternal role models. This argument is supported by Dunn and Holtz-Eakin (2000), who found that sons of self-employed fathers more often enter selfemployment than sons of self-employed mothers, and by Mancuso (1974), who found that the "primary motivation for the entrepreneur's high ego and need for achievement is based upon his relationship with the father" (cf. p. 20).

Summing up, social learning theory and existing literature suggest that there is an overall positive relationship between the presence of parental role models and an individual's decision to become selfemployed. However, this effect may be stronger for paternal than for maternal role models, leading to the following hypotheses:
H1a In entrepreneurial families, there is a positive relationship between the presence of parental self-employed role models and offspring being self-employed.

$\mathrm{H} 1 \mathrm{~b}$ In entrepreneurial families, there is a positive relationship between the presence of paternal self-employed role models and offspring being self-employed.

H1c In entrepreneurial families, there is a positive relationship between the presence of maternal self-employed role models and offspring being self-employed.

H1d In entrepreneurial families, the positive relationship between the presence of selfemployed role models and offspring being self-employed is stronger for paternal selfemployed role models than for maternal selfemployed role models.

\subsection{Parental role models, personality,} and self-employment

While the above arguments and studies support the notion that, through social learning, parental role models influence the decisions of individuals to become self-employed, there appears to be variance in the extent of this influence. Findings in the literature are not uniformly in favor of a strong "parental role model" effect. Insignificant or inconsistent results are reported from studies in the USA (Brenner et al. 1991; Kim et al. 2006; Matthews and Moser 1996) and Singapore (Ghazali et al. 1995). It appears that the effect of parental role models on individual decisions to enter self-employment is not universal, but may be more complex than sometimes assumed.

One factor that may influence the relationship between role models and career decisions is the personality of the individuals. Personality refers to relatively enduring patterns of thoughts, feelings, and actions that can be quantitatively assessed and show some degree of cross-situational consistency (Pervin and John 1999). Personality determines, partly, how individuals sense (Holland 1985), interpret (Rauch and Frese 2000), and act on (Hunt and Adams 1998; Caprana and Cervone 2000) information and stimuli they receive from their environment and thus their social learning processes. For example, Ajzen's 
review (1987) and related work by Bagozzi et al. (1992) note that individuals with an internal locus of control are not strongly influenced by social norms introduced to them by their family. These studies show the reduced effect of role models and social learning because of certain personality traits influencing information processing and learning.

Latest meta-analyses and reviews (Mueller 2004; Rauch and Frese 2007; Zhao and Seibert 2006) state the importance of considering an individual's personality when examining self-employment decisions: “...entrepreneurship research cannot develop a consistent theory about entrepreneurship if it does not take personality variables into account as well" (Rauch and Frese 2007, p. 29). Since the presence and behaviors of parental role models represent environmental stimuli for individuals, their propensity to act based on these parental role models is contingent on their personality characteristics. In line with this argument, Kuratko and Hodgetts (2001) stated that behavior can only be described by the interaction of personal and situational factors (such as the presence of role models), and others have also argued that a theory which does not consider these factors simultaneously overly reduces the complexity of the self-employment process (Korunka et al. 2003; Tett and Burnett 2003). It appears that personality and role models complement each other and conjointly rather than independently influence selfemployment decisions.

One of the most common classifications of personality relates to the "Big Five" (Costa and McCrae 1992). The Big Five refer to an individuals' degree of neuroticism (anxious and self-conscious), conscientiousness (hard working and persisting), agreeableness (cooperative and altruistic), extraversion (cheerful and seeks excitement), and openness (receptivity to new experiences). In the entrepreneurship literature, various studies have investigated how the Big Five influence an individual's decision to become self-employed. For example, a range of authors identified individuals intending to start their own business as being more emotionally stable and more open compared with others intending to become employed (Chen et al. 1998; Crant 1996; Simon et al. 1999; Singh and DeNoble 2003). Furthermore, the Big Five not only successfully distinguish individuals intending to become self-employed from those who do not but also help compare entrepreneurs with managers. Zhao and Seibert (2006) found entrepreneurs to be more conscientious, open, and emotionally stable while being less agreeable than managers. The notion that the Big Five personality dimensions play an important role in an individual's decision to become self-employed is further corroborated by recent reviews and meta-analyses (Mueller 2004; Rauch and Frese 2000, 2007; Zhao and Seibert 2006).

We limit our attention to openness because several empirical studies have consistently established that openness plays an important role in individuals' selfemployment decisions (Zhao and Seibert 2006; Engle et al. 1997; Singh and DeNoble 2003; SchmittRodermund 2004). In contrast, the impact of other personality variables has not been established unambiguously, and their impact on self-employment decisions is questionable (Gartner 1988; Cooper and Gimeno-Gascon 1992; Rauch and Frese 2007; Baum et al. 2007).

It appears that the effect of social learning varies between high- and low-openness individuals, because openness influences the kind of information and environmental stimuli to which individuals respond. Individuals with high openness will respond more to behaviors and actions of people other than their parents. Family contexts represent highly familiar environments, and high openness can complement the presence of parental role models; that is, we focus on the moderating effect of openness on the role model-self-employment relationship.

By definition, openness is the tendency to be creative, original, and receptive to new experiences (Singh and DeNoble 2003). Open individuals have broad interests, are imaginative, and enjoy the esthetics of their environment (Zhao and Seibert 2006); that is, open individuals are responsive to new ideas and incorporate information and stimuli outside their daily experiences and established patterns of thoughts into their behavior and actions. In contrast, individuals with low openness are conventional and comfortable with well-established methods and topics (Singh and DeNoble 2003); they favor the status quo. Therefore, the more open the individual, the more likely she/he is to learn from others outside familiar contexts.

Applied to entrepreneurial families, it appears that, through social learning experiences outside the family, more open offspring may incorporate ideas about potential career paths different from those of 
their parents - career paths that they would not have considered when attending only (or mainly) to the family context (Stavrou and Swiercz 1998). Moreover, the more open the individual, the higher their creativity (Singh and DeNoble 2003) and tendency to experiment with behavioral patterns different from those of their parents (Stavrou and Swiercz 1998). These individuals are less likely to be influenced by family members and parental role models; instead, they may come up with a variety of potential career opportunities that are new and unknown to them and their family (Stavrou and Swiercz 1998). Given that they find one of these opportunities attractive to pursue, open individuals might not follow their parental role models' footsteps but choose a career that no one in their family and social environment has taken before.

In contrast, low-openness individuals tend to focus their attention on what they know, such as their parents' daily observed behavior. They attend to little environmental stimuli and information from outside their familiar context and are often reluctant to integrate those stimuli into their mental models and career decisions. Therefore, low-openness individuals will have a narrower imagination and be less creativity in their career choice than high-openness individuals and thus may be more likely to choose a career similar to those of their family members. That is, if these individuals live in an entrepreneurial family, they will likely stay close to what they know (Singh and DeNoble 2003), following the career path of their parents and becoming self-employed.

Finally, the effect of openness on the parental role model-self-employment relationship may be different for paternal and maternal role models because children generally learn gender roles (shared beliefs about what role behaviors are appropriate for each sex) and gender stereotypes (shared beliefs about what psychological traits are appropriate for each sex) from their social environment (Deaux and Kite 1993; Eddleston et al. 2006; Konrad et al. 2000), which in turn influences their decision policies in later life (Ruble and Martin 1998).

In entrepreneurial families, an orientation toward entrepreneurship and self-employment is characterized by proactiveness, aggressiveness, and autonomy (Lumpkin and Dess 1996) —attributes that are typically associated with masculinity and the role behavior of fathers (cf. Bem 1974). Therefore the motivating effect of paternal role models is likely to be stronger for less open individuals because their father being an entrepreneur is consistent with their existing belief of gender roles and stereotypes; ${ }^{1}$ that is, self-employment of mothers will appear less consistent with what children expect based on their learned gender roles and stereotypes than selfemployment of fathers.

In contrast, the more open that offspring are to new influences that contradict their existing beliefs (Singh and DeNoble 2003), the more likely they are to accept inconsistencies between self-employed mothers and learned female gender roles and stereotypes, and thus the more motivated they may be to follow nontraditional maternal role models when choosing their occupation; for example, if a society mainly defines women through roles connected to family and household responsibilities, female entrepreneurship is implicitly interpreted as less desirable (Bruin et al. 2007).

In sum, we hypothesize that individuals with high openness are less influenced by role models within an entrepreneurial family than individuals with low openness, and that this effect is different for maternal and for paternal role models:

$\mathrm{H} 2 \mathrm{a}$ In entrepreneurial families, the positive relationship between the presence of parental self-employed role models and offspring being self-employed is stronger for individuals with low openness than for individuals with high openness.

$\mathrm{H} 2 \mathrm{~b}$ In entrepreneurial families, the positive relationship between the presence of paternal self-employed role models and offspring being self-employed is stronger for individuals with low openness than for individuals with high openness.

$\mathrm{H} 2 \mathrm{c}$ In entrepreneurial families, the positive relationship between the presence of maternal self-employed role models and offspring being self-employed is stronger for individuals with high openness than for individuals with low openness.

\footnotetext{
$\overline{1}$ We acknowledge that these arguments may not hold for feminine societies, and that the differences between maternal and paternal role models may diminish. Our data is based on a masculine society (Germany).
} 


\section{Data and methodology}

\subsection{Sample and data collection}

The sample of our study is composed of alumni from eight German universities. We designed this crosssectional study with three issues in mind. Firstly, we were interested in a sample of individuals with the same major. According to Brüderl et al. (1992), the major (especially business administration) has an important influence on the likelihood that alumni will become self-employed sooner or later after their studies. Secondly, we selected individuals who had already started their professional career; therefore, chose alumni who graduated in various years (19802004) as the target group. Thirdly, we used a singlenation sample (Germany) in order to control for potential international and cultural variations (e.g., regarding gender roles).

We identified a sample of 2,699 alumni from eight different German universities with the help of alumni organizations. We contacted these alumni via email and invited them to participate in our study. As part of the invitation, we described the purpose of our study, the duration of the questionnaire, and the topics included. To minimize response bias tendencies, we assured the participants that their data would be treated confidentially and analyzed anonymously. We also stressed the value of responses being congruent with their beliefs (Stavrou and Swiercz 1998). For data collection, we used an online instrument where participants were asked to provide information about their personal background, personality, and occupational status.

In sum, 552 alumni representing all eight universities participated, yielding a response rate of $20.5 \%$. Due to missing data, however, we had to eliminate 91 of these 552 alumni. Thus, our final sample size was 461. On average, these participants were 33.2 years old (standard deviation 6 years), 27.2\% of them were female, and $61.8 \%$ lived with their partner. Moreover, $36.4 \%$ of the participants had a self-employed father, $12.3 \%$ a self-employed mother, and for $39.1 \%$ at least one parent was self-employed. Finally, $26.4 \%$ of the participants were self-employed.

We further compared early and late respondents to test for nonresponse bias. However, early and late respondents did not demonstrate significant differences with regard to personality, role model, or self- employment variables, suggesting that nonresponse bias is not a problem in our set of data.

\subsection{Measures}

\subsubsection{Dependent variable}

The dependent variable of our study is binary and indicates whether a person is currently self-employed or not. We acknowledge that it is a limitation of our dataset that we do not have information on the previous careers of the participants. That is, we miss those who had been self-employed in the past but were not self-employed any more at the time of our survey. Since the average participant of our study is relatively young (33.2 years), however, it is reasonable to believe that few would have pursued more than one career up to this point in time.

\subsubsection{Independent variables}

We used binary variables to indicate whether the participants were confronted with parental, paternal, or maternal self-employed role models. First, parental role model was coded as +1 if either the father or the mother of the individual was self-employed, and as -1 otherwise. Second, paternal role model was coded as +1 if the father of the participating individual was self-employed, and -1 otherwise. Finally, maternal role model was coded as +1 if the mother of the participating individual was selfemployed, and -1 otherwise.

To measure the individual's openness, we used stable (Costa and McCrae 1997) and universally examined constructs, derived from the Big Five trait inventory. This inventory is based on the German version of the NEO-Five-Factor-Inventory (NEOFFI) developed by Costa and McCrae (1992), which shows high factor validity. The entire questionnaire contains 30 pairs of adjectives (Schallberger and Venetz 1999). The items were measured on a sixpoint Likert-type scale. The reliability of personality variables in our dataset ranged from 0.69 to 0.88 (Cronbach's alpha).

\subsubsection{Control variables}

We used a total of ten control variables that potentially influence our results. First, age stands 
for the age of the participant. The older the individual, the more likely she/he has entered self-employment in the past. We chose gender as a control variable (coded -1 for males and +1 for females). Former studies showed that more men than women are self-employed (Minniti et al. 2005). Further, we examined the marital status of the individual, asking whether she/he lived with a partner or not. According to Sternberg et al. (2005), most self-employed persons are married or engaged in a partnership. We also controlled for the success of the individual's business, because more successful individuals are more likely to continue self-employment. We used the scale developed by Schenk and Frese (Schenk 1998) to measure the individual's perception of goal achievement of self-employment, and we controlled for the personal income of the individual. Since entrepreneurial knowledge is a major driver of individuals' decisions to become entrepreneurs (Krueger 2000), we used a binary variable, education, indicating whether the individual had attended any entrepreneurship courses at a university. Finally, we controlled for possible influences of other personality traits potentially explaining variance in entrepreneurial behavior (Zhao and Seibert 2006). We measured extraversion, agreeableness, conscientiousness, and neuroticism by using the well-established German version of the NEO-FFI (Schallberger and Venetz 1999) with six-point Likert-type scales. The metaanalysis by Zhao and Seibert (2006) found that self-employed people differ in their personality characteristics from salaried workers.

We would like to emphasize that we gathered data by surveying business administration alumni, but we were not able to independently verify the survey results by comparing them with other data sources; for example, we could not verify whether the individuals' parents were indeed self-employed. We believe, however, that this is a minor problem, because the decisions of individuals are based on their perceptions of the environment rather than on environmental characteristics (March and Shapira 1987; Das and Teng 2001). That is, even if the individuals' parents are not self-employed according to the legal form of their business, or the parents are only part-time self-employed, the individuals' perceptions of them being self-employed determines the individuals' decision policies to become selfemployed themselves.
Furthermore, we do not consider common method bias as a major issue in our data. Common method bias arises when more variance in the data is attributable to the method used than to the variables measured (Podsakoff et al. 2003). Following Podsakoff et al. (2003), we took several steps to minimize common method bias. First, we guaranteed respondent anonymity, which makes it unlikely that survey participants will systematically bias their responses toward socially desirable answers. Second, we used Harman's single-factor test (Podsakoff et al. 2003) to check whether one single factor accounts for most of the variance in the data, which can be attributed to a common method bias. No such factor was found. Finally, note that only personality variables and goal achievement are measured as psychological constructs, while the other variables (gender, age, marital status, education, income, role models) are objective and not based on attitudes or opinions.

\section{Results}

Table 1 presents the descriptive statistics and Pearson correlations of our research variables. All correlations between independent variables are modest and range from -0.269 to 0.459 . The correlations between parental, paternal, and maternal role models range between 0.453 and 0.917 , because paternal and maternal role models are included in the parental one. Hence, we used separate analyses for the three independent variables. Although not reported herein because of space limitations, we also examined multicollinearity by calculating variance inflation factors. All values were below acceptable thresholds for multivariate analyses (Hair et al. 1998).

Since our dependent variable is binary, we used a logit regression model to test the effect of our independent variables. Table 2 displays the results of our analysis. We calculated nine models including the different moderators (Baron and Kenny 1986).

We first entered the control variables gender, age, marital status, education, goal achievement, income, and the personality variables extraversion, agreeableness, conscientiousness, neuroticism, and openness (model I). This base model has a pseudo- $R^{2}$ of $14.1 \%$. In the next step, we added the role model variables, i.e., either parental role models (model II), paternal role models (model III), maternal role models (Model IV), 


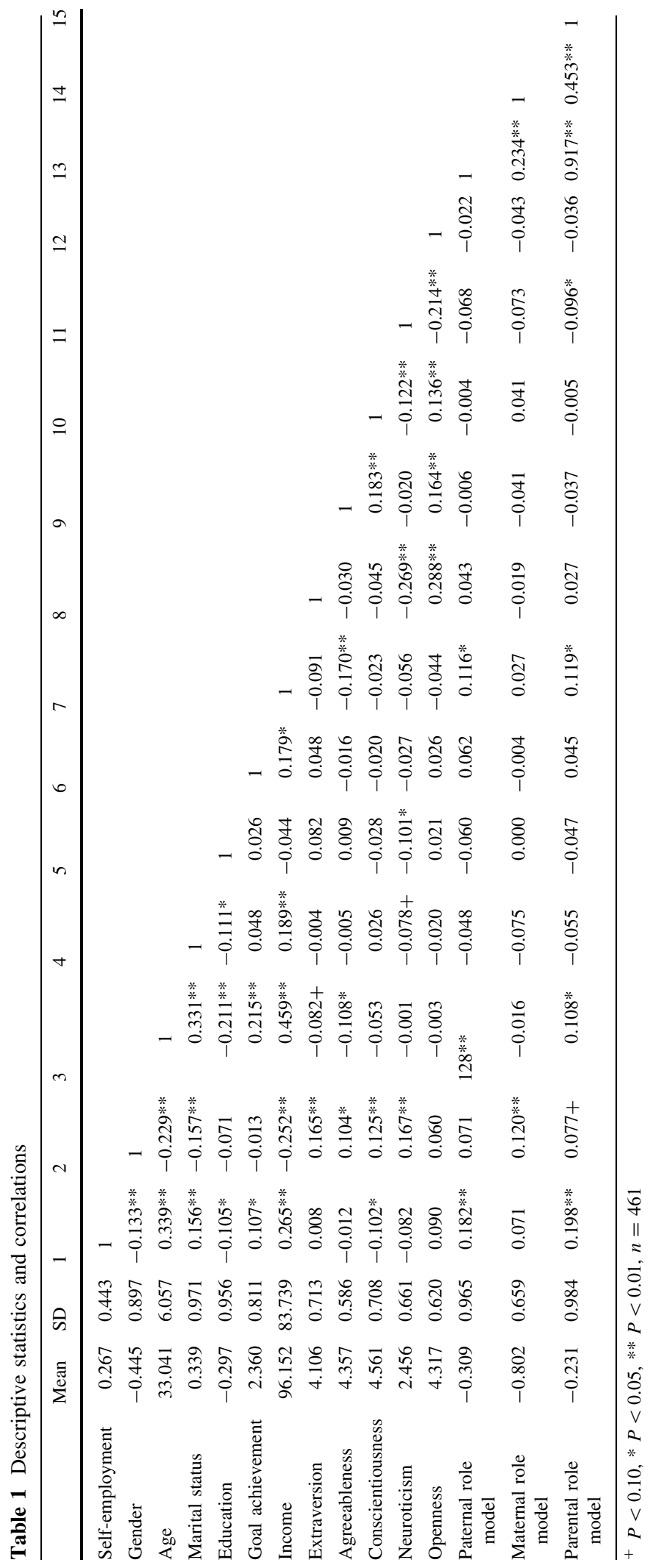


Table 2 Logit regression results for the decision to become self-employed

\begin{tabular}{|c|c|c|c|c|c|c|c|c|c|}
\hline & Model I & Model II & Model III & Model IV & Model V & Model VI & Model VII & Model VIII & Model IX \\
\hline Constant & -5.064 & -4.862 & -4.784 & -0.4887 & -0.4678 & -4.828 & -4.752 & -4.953 & -4.779 \\
\hline \multicolumn{10}{|l|}{ Control variables } \\
\hline Gender & -0.089 & -0.168 & -0.148 & -0.135 & -0.177 & -0.167 & -0.149 & -0.148 & -0.195 \\
\hline Age & $0.096 * *$ & $0.090 * *$ & $0.090 * *$ & $0.097 * *$ & $0.091 * *$ & $0.088 * *$ & $0.088 * *$ & $0.098 * *$ & $0.091 * *$ \\
\hline Marital status & 0.119 & 0.169 & 0.161 & 0.132 & 0.168 & 0.165 & 0.147 & 0.126 & 0.147 \\
\hline Education & -0.179 & -0.166 & -0.165 & -0.183 & -0.168 & -0.183 & -0.177 & -0.173 & -0.166 \\
\hline Goal achievement & 0.089 & 0.106 & 0.094 & 0.095 & 0.098 & 0.119 & 0.108 & 0.101 & 0.126 \\
\hline Income & $0.004 *$ & $0.003 *$ & $0.003 *$ & $0.003^{*}$ & $0.003 *$ & $0.003^{+}$ & $0.003 *$ & $0.003 *$ & $0.003 *$ \\
\hline Extraversion & 0.019 & 0.022 & 0.009 & 0.038 & 0.025 & -0.003 & -0.024 & 0.040 & -0.010 \\
\hline Agreeableness & 0.144 & 0.179 & 0.149 & 0.158 & 0.158 & 0.151 & 0.115 & 0.152 & 0.106 \\
\hline Conscientiousness & $-0.396^{*}$ & $-0.413 *$ & $-0.406 *$ & $-0.410 *$ & $-0.417^{*}$ & $-0.400 *$ & $-0.392 *$ & $-0.410 *$ & $-0.400 *$ \\
\hline Neuroticism & -0.288 & -0.214 & -0.241 & -0.254 & -0.221 & -0.243 & -0.268 & -0.244 & -0.232 \\
\hline Openness & $0.409 *$ & $0.470 *$ & $0.461 *$ & $0.428 *$ & $0.469 *$ & $0.450 *$ & $0.448 *$ & $0.596 *$ & $0.734 *$ \\
\hline \multicolumn{10}{|l|}{ Main effects } \\
\hline Parental role model & & $0.438 * *$ & & & & $0.465 * *$ & & & \\
\hline Paternal role model & & & $0.370 * *$ & & $0.337 * *$ & & $0.394 * *$ & & $0.368 * *$ \\
\hline Maternal role model & & & & $0.334^{+}$ & 0.233 & & & $0.329^{+}$ & 0.214 \\
\hline \multicolumn{10}{|l|}{ Interaction effects } \\
\hline $\begin{array}{l}\text { Parental role } \\
\text { model } \times \text { openness }\end{array}$ & & & & & & $-0.390 *$ & & & \\
\hline $\begin{array}{l}\text { Paternal role } \\
\text { model } \times \text { openness }\end{array}$ & & & & & & & $-0.433 *$ & & $-0.487 *$ \\
\hline $\begin{array}{l}\text { Maternal role } \\
\text { model } \times \text { openness }\end{array}$ & & & & & & & & 0.238 & 0.387 \\
\hline \multicolumn{10}{|l|}{ Model specifications } \\
\hline $\mathrm{Chi}^{2}$ & 74.80 & 88.00 & 84.09 & 78.42 & 85.77 & 92.01 & 89.06 & 79.22 & 92.52 \\
\hline Pseudo- $R^{2}$ & $14.06 \%$ & $16.54 \%$ & $15.80 \%$ & $14.74 \%$ & $16.12 \%$ & $17.29 \%$ & $16.74 \%$ & $14.89 \%$ & $17.39 \%$ \\
\hline
\end{tabular}

or paternal and maternal role models (model V). As compared with the base model, pseudo- $R^{2}$ improved to $16.5 \%$ (model II), $15.8 \%$ (model III), $14.7 \%$ (model IV), and $16.1 \%$ (model V), respectively. Finally, we added the interaction effects between openness and parental role models (model VI), openness and paternal role models (model VII), openness and maternal role models (model VIII), and openness and paternal and maternal role models (model IX), correspondingly. Again, these models improved in comparison with the main-effects-only models as shown by their pseudo- $R^{2}$ values of $17.3 \%$ (model VI), $16.7 \%$ (model VII), $14.9 \%$ (model VIII), and $17.4 \%$ (model IX), respectively.

With regard to our main-effect research hypotheses, we find a significant positive relationship (model II, coefficient $=0.438, P<0.01$ ) between the presence of a parental role model and the likelihood that the individual is self-employed. Thus, hypothesis 1a is supported. Moreover, we find a significant positive relationship (model III, coefficient $=0.370, P<0.01$ ) between the presence of paternal role models and the likelihood of being selfemployment, and a marginal significant positive relationship between maternal role models and the likelihood of being self-employment (model IV, coefficient $=0.334, \quad P<0.10$ ). When both role model variables are added at the same time (model V), the effect of the father remains significant (coefficient $=0.337, P<0.01$ ) whereas the effect of the mother becomes insignificant (coefficient = $0.233, P>0.19$ ). Thus, there is support for hypothesis $1 \mathrm{~b}$, but only mixed support for hypothesis $1 \mathrm{c}$. In order to test whether the effect of paternal and 
maternal role models differ significantly, we calculated chi-square values to test the null hypothesis of equal influence (in model V). This null hypothesis could not be rejected at a statistically significant level (chi-square $=0.20, P>0.65$ ). Thus, hypothesis $1 \mathrm{~d}$ is not supported.

The main purpose of our study, however, was to explore whether the openness of the individual can explain why role models have a different effect on some individuals than on others. Indeed, our data in Table 2 show that there is a significant interaction effect between openness and the presence of parental role models (model VI, coefficient $=-0.390, P<$ $0.05)$. Moreover, the interaction between openness and the presence of paternal role models is significant (model VII, coefficient $=-0.433, P<0.05$ ). We do not, however, find a significant interaction between the presence of maternal role models and openness (model VIII, coefficient $=0.238, P>0.38$ ). These results hold when we add interactions between openness with paternal role models (coefficient = $-0.487, P<0.05$ ) and maternal role models (coefficient $=0.387, P>0.17$ ) at the same time (model IX). Interestingly, the difference between the interaction of openness with paternal and the interaction of openness with maternal role models is significant, as the null hypotheses (both being equal) can be rejected (chi-square $=5.21, P<0.05$ ). Also note that the interaction coefficients for maternal role models and paternal role models have opposite signs, suggesting a different influence of openness in the presence of both types of role models. ${ }^{2}$

In order to better understand these interactions, based on the coefficients of models VI and VII, we plot them on an $x$-axis of independent variables (role model) and a $y$-axis of self-employment, with plots representing low openness (one standard deviation below the mean) versus high openness (one standard deviation above the mean) (Fig. 1). Figure 1a illustrates that the relationship between the presence of a parental role model and the likelihood that the individual is self-employed is more positive when

\footnotetext{
${ }^{2}$ We also calculated main-effect and interaction models for the case that both father and mother are self-employed. We did not find any significant relationship. Since only 38 of our 461 respondents $(8.2 \%)$ had two parents who were self-employed, the rarity of this event may make it unlikely to obtain statistically meaningful results.
}

A

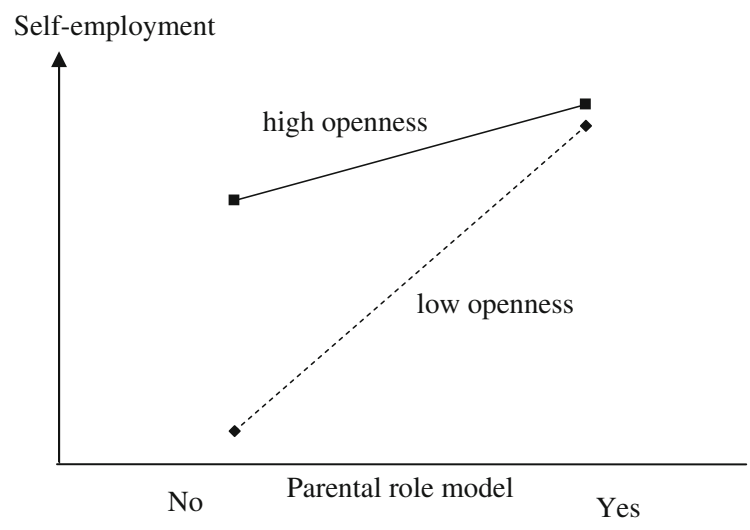

B

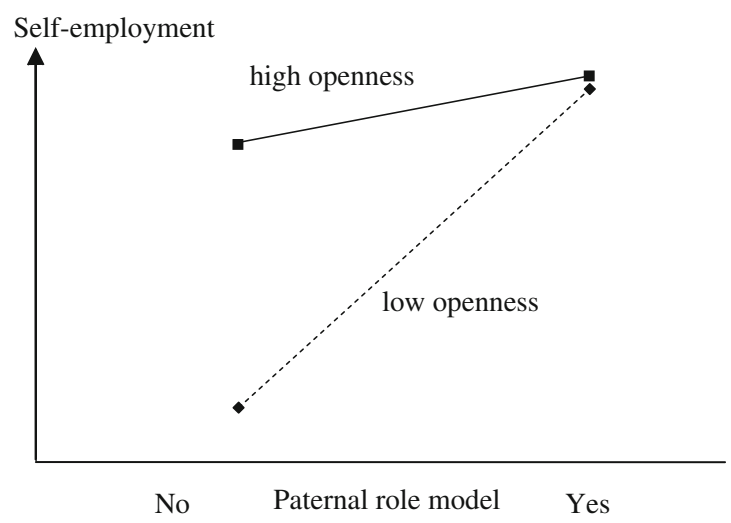

Fig. 1 Interactions (model VI and VII) between openness and parental role model (a) and openness and paternal role model (b)

the individual scores low on openness than when the individual scores high on openness, supporting hypothesis $2 \mathrm{a}$. Moreover, Fig. 1b demonstrates that the relationship between the presence of paternal role models and the likelihood that individuals is selfemployed is more positive when the individual scores low on openness than when the individual scores high on openness. The nature of this interaction supports hypothesis $2 \mathrm{~b}$. As the interaction between maternal role model and openness did not become significant, hypothesis $2 \mathrm{c}$ is not supported.

\section{Discussion and implications}

In this paper, we apply social learning theory (Bandura 1986) to gain deeper understanding of the 
effect of parental role models in entrepreneurial families. Drawing from data on 461 alumni from eight German universities, we found that parental, paternal, and maternal role models increase the likelihood that family offspring become selfemployed. Even more importantly, we found that, the more open the individual, the weaker the effect of parental and paternal role models. These findings expand the literature on entrepreneurial families, role models, and the psychology of the entrepreneur in several ways.

First, our study expands the general literature on entrepreneurial role models (parental and others) by taking into account the personality of self-employed individuals. So far, most work on role models has only analyzed direct effects (Davidsson and Honig 2003; De Witt and Van Winden 1989; Matthews and Moser 1996), whereas we identify openness as a contingency variable moderating the effect of role models. In existing literature the effect of parental role models on children's self-employment decisions has often been inconclusive (Brenner et al. 1991; Ghazali et al. 1995; Kim et al. 2006), and therefore the introduction of contingency variables appears to be one way to resolve potentially conflicting results. Our work supports this view by showing that the personality of an individual (specifically her/his openness) moderates the impact of role models in the context of entrepreneurial families. Future research on (parental and other) role models may go beyond the analysis of main-effect-only models and include interactions between role models and other variables describing the psychology of the selfemployed.

Our work also complements existing literature on parental role models in entrepreneurial families. This literature has emphasized the importance of parental role models in the motivation of children to take over family businesses (Dyer et al. 1994; Dunn and HoltzEakin 2000). Our results are consistent with these studies, because we found that the likelihood of children becoming self-employed is higher in families where self-employed parental role models are present than in families where parents are not selfemployed. With respect to the role of offsprings' characteristics in family businesses, Dumas (1990) focused on the personality development of the daughter-successor in terms of identity formation in family businesses, but did not investigate personality characteristics as we did. Other individual characteristics that have been examined include the offspring's age (Stavrou 1999; Kimhi 1997), gender (Dumas 1989; Stavrou 1999; Sharma and Irving 2005), or motivation and abilities (Le Breton-Miller et al. 2004). However, most studies in the family business literature focus on the parents (e.g., age or gender) (Le Breton-Miller et al. 2004; Marshall et al. 2006; Davis and Harveston 1998) but neglect characteristics of the next generation. Our results therefore extend existing work on entrepreneurial families and family businesses because they suggest that the offsprings' openness is an important determinant of their acceptance of and response to the presence of parental role models, thereby influencing the likelihood that they will follow their parents in becoming self-employed. Thus, our results imply that openness may help to explain why some children choose to join the family business while others do not.

In distinguishing between paternal and maternal role models our work allows us to gain a more detailed picture of the effect of parental role models in entrepreneurial families. Most existing studies have not differentiated between paternal and maternal role models (e.g., Scott and Twomey 1988; Dunn and Holtz-Eakin 2000; Schmitt-Rodermund and Vondracek 2002; Kim et al. 2006). First, we show that both maternal and paternal role models have a significant direct influence on the offspring's decision to become self-employed. Our study, however, showed that the effect of paternal role models depends on the openness of those individuals, whereas the effect of maternal role models does not (at least not at a statistically significant level). Moreover, we found that the moderating impact of openness significantly differs in regard to paternal and maternal role model effects.

It is important to note that the role model effects that we find for our German sample may differ across societies and cultures (Hofstede 1980). For example, in some developing countries prevalent gender roles and gender stereotypes are basically incompatible with self-employed mothers, since women are expected to care for and nurture their families rather than pursue careers (Birley 1989; Chitsike 2000; Brush et al. 2006). Similarly, other research suggests that, in some countries with early transition economies, institutional structures prevent women from founding their own businesses (Aidis et al. 2007), 
suggesting that self-employed women role models may be rare and inconsistent with prevalent gender roles and stereotypes. It is questionable whether in these countries even highly open individuals can be motivated by maternal role models to enter selfemployment. Finally, a 17-country study by Mueller (2004) found that the influence of personality on entrepreneurial behavior differs across cultures. Thus, in some cultures the moderating effect of openness on the role model-self-employment decision relationship may be stronger than in other cultures. We encourage scholars to investigate whether our results are robust across cultures and national contexts, and whether differences exist between societies.

Our study also adds to literature on the personality of entrepreneurs. Although some scholars have questioned whether personality variables have a substantial influence on entrepreneurial behavior (Gartner 1988; Chell 1985) and empirical results have sometimes been inconclusive (Rauch and Frese 2007; Zhao and Seibert 2006), the majority of authors agree that personality variables have a direct impact on the decision to become self-employed. For example, a recent comprehensive meta-analytical review on personality and entrepreneurial behavior (Zhao and Seibert 2006) found that entrepreneurs score higher than managers on conscientiousness and openness, but lower on neuroticism and agreeableness (no significant differences were found for extraversion). In line with this study, our results in Table 2 show a significant and positive relationship between openness and selfemployment, and no significant relationship between extraversion and self-employment. However, in contrast to Zhao and Seibert's study (2006), we do not find significant relationships between agreeableness and self-employment or between neuroticism and selfemployment. Another recent meta-analysis by Rauch and Frese (2007) found that traits matched to the task of running a business (e.g., need for achievement, innovativeness, stress tolerance) are more strongly linked to business creation than more general traits such as the Big Five. The differences between these two and our study may partly be explained by the different dependent variables-Zhao and Seibert (2006) compared entrepreneurs and managers, and Rauch and Frese (2007) focused on business creation only, whereas we compared self-employed and nonself-employed individuals and included those who took over an existing (family) business.
Interestingly, we found a significant negative relationship between conscientiousness and selfemployment, which is in contrast to Zhao and Seibert's (2006) finding of a significant positive relationship. Conscientiousness refers to an individual's motivation to work hard and achieve important goals, an often-described motivation for individuals to become self-employed and persist with selfemployment (Shane et al. 2003). Perhaps one explanation is that the booming job market in 2005 (the time of our survey) in Germany offered better opportunities to achieve high goals by becoming employed at a successful company than by choosing self-employment. Another possible explanation for our finding stems from the process perspective that each phase of the entrepreneurship process has its own unique set of critical activities and outcome variables. According to Baron and Markman (2005), effects of personality traits might change over the different phases of founding a venture. They describe openness to be important for the early phases in the process when opportunity recognition is necessary, and conscientiousness to be of importance in the postlaunch phase when the entrepreneur should focus on the delivery of services and products.

Meta-analytic reviews by both Zhao and Seibert (2006) and Rauch and Frese (2007) emphasize that interaction variables may be necessary to better understand the effect of personality in entrepreneurial behavior. Our study supports this view, because we show that the personality of an individual can enhance or diminish the effects of environmental variables (the presence of role models) on an individual's decision to become self-employed. Using personality as a moderator may open up a number of research avenues that potentially deepen our understanding of entrepreneurial psychology. For example, while we know that certain cognitive factors (e.g., knowledge and skills) as well as entrepreneurial motivations (desire for independence, etc.) impact the entrepreneurial process (Shane et al. 2003), we do not yet know whether these effects differs for individuals with different personality characteristics. Entrepreneurship scholars can make important contributions when using personality variables as moderators for investigating entrepreneurial decision-making.

Our study also addresses a practical issue we consider to be of great importance for family business leaders: how to motivate offspring to take over the 
family business. Specifically, the interaction of parental role models and the personality of the offspring suggests that only serving as a role model might be insufficient to motivate the offspring to take over the business; for example, when the role model is provided by the father trying to influence a highly open offspring to take over the family business, potential conflicts might arise. In this case, additional motivational measures may be necessary to prevent the offspring from seeking a career path outside the family business. These include offering her/him high levels of autonomy (Shane et al. 2003) and creativity within the family business, training her/him in entrepreneurship and leadership (Krueger 2000), and making the business as successful as possible (Dunn and HoltzEakin 2000). These steps may be crucial to ensure that the business is passed onto the next generation.

\subsection{Limitations and future research}

As with all studies, there are a number of limitations that offer opportunities for future research. Firstly, we focus on the individual's decision to become selfemployed. This variable has the advantages that it is consistent with many existing studies and models of entrepreneurship and entrepreneurial behavior (Douglas and Shepherd 2000, 2002; De Witt and Van Winden 1989; White et al. 2007), and with macrolevel studies investigating the impact of self-employment on economic development (Thurik et al. 2008; Sternberg 2005). However, there are also limitations associated with this dependent variable. For example, we cannot differentiate between individuals deciding to start a new firm, take over an existing firm from someone else, or take over an existing family business. Individuals may be less likely to start up their own business because newly started firms are more likely to fail than existing firms (Stinchcombe 1965), and the decision to take over a family firm is special because it is influenced by family processes and dynamics (Ibrahim et al. 2001; Kets de Vries 1993; Liebowitz 1986; Morris et al. 1997; Rodriguez et al. 1999). Future research can make important contributions if it distinguishes between these decisions.

Secondly, our dataset does not provide information about the offspring's involvement in a family business before her or his decision to become selfemployed. This involvement can have a profound impact on the decision; for example, when individuals are involved in a family business early in their life the business can become part of their identity (Dumas 1990). Indeed, Stavrou (1999) found that individuals who had previously worked in a family business were more willing to take over that business. On the other hand, involvement can also diminish the offspring's intentions to take over a family firm, particularly when the owner is unable to let go and give up control, thereby leading to conflict between the owner and the offspring, and pushing the offspring to seek an alternate career (Landsberg 1981; Stavrou 1999). Furthermore, conflict between an owner and offspring could lead to "the parental quashing of attempts at innovation by youngergeneration members" (Hoy and Verser 1994, p. 20) and thus counteract succession within the family. These problems may also prevent the offspring from founding her or his own firm, because they demonstrate the difficulties that can arise with one's own children. We hope that other authors who have access to data on offsprings' involvement in a family business will investigate these issues.

Thirdly, while our theory based on social learning arguments suggests that openness moderates the impact of parental role models on offsprings' decision to become self-employed, we would like to acknowledge the possibility that the presence of parental role models moderates the (direct) effect of openness on this decision. That is, one can argue that the effect of openness is stronger when no parent is self-employed, because in the absence of parental role models individuals may be more driven by their own personality. These two possibilities cannot be distinguished statistically with the data we have at hand. $^{3}$

Finally, research on entrepreneurial families has found that family dynamics such as conflict, parental authority, and control change from generation to generation (Kellermanns and Eddleston 2004) and influence whether children decide to take over the family business of their parents or not (Kets de Vries 1993; Liebowitz 1986; Rodriguez et al. 1999). Furthermore, this influence may depend on whether one or both parents are involved in a family business; for example, both parents working in the family business leads to diminished family-work boundaries, which

\footnotetext{
$\overline{3}$ We thank an anonymous reviewer for pointing out this alternative interpretation of our results.
} 
might result in greater family-work role conflict as well as family disharmony (Beehr et al. 1997). It is to be assumed that these circumstances have an impact on the decision of the offspring to take over the business. Future research can make important contributions if it explores the effects of involving both parents in the firm, family dynamics, and communication patterns in entrepreneurial families.

\subsection{Conclusions}

Our study shows that role models in entrepreneurial families are important motivators for becoming selfemployed. We found similar effects for parental, paternal, and maternal role models. However, the role model impact depends on individual personality, and those individuals who are less open experience a stronger impact. These findings demonstrate the necessity to consider both the individual's personality as well as her/his environment when explaining selfemployment. The results expand the literature on entrepreneurial role models, family businesses, and the psychology of the entrepreneur.

Open Access This article is distributed under the terms of the Creative Commons Attribution Noncommercial License which permits any noncommercial use, distribution, and reproduction in any medium, provided the original author(s) and source are credited.

\section{References}

Aidis, R., Welter, F., Smallbone, D., \& Isakova, N. (2007). Female entrepreneurship in transition economies: The case Lithuania and Ukraine. Feminist Economics, 13(2), 157-183.

Ajzen, I. (1987). Attitudes, traits, and actions: Dispositional prediction of behavior in personality and social psychology. In L. Berkowitz (Ed.), Advances in experimental social psychology (Vol. 20, pp. 1-63). New York: Academic.

Bagozzi, R., Baumgartner, H., \& Yi, Y. (1992). State vs. action orientation and the theory of reasoned action. Journal of Consumer Research, 18(4), 505-518.

Bandura, A. (1986). Social foundations of thought and action. Engelwood Cliffs, NJ: Prentice-Hall.

Bandura, A., \& Walters, R. (1963). Social learning and personality development. New York: Holt, Rinehart \& Winston.

Baron, R. M., \& Kenny, D. A. (1986). The moderator-mediator variable distinction in social psychological research: Conceptual, strategic and statistical considerations. Journal of Personality and Social Psychology, 51(6), 1173-1182.
Baron, R. A., \& Markman, G. D. (2005). Toward a process view of entrepreneurship: The changing relevance of individual-level variables across phases of new firm development. In M. A. Rahim, R. T. Golembiewski, \& K. D. Mackenzie (Eds.), Current topics in management (Vol. 9, pp. 45-64). New Brunswick, NJ: Transaction.

Barrick, M. R., \& Mount, M. K. (1991). The big five personality dimensions and job performance: A meta-analysis. Personnel Psychology, 44(1), 1-26.

Baum, J. R., Frese, M., \& Baron, R. (2007). The psychology of entrepreneurship. New Jersey: Lawrence Erlbaum.

Baum, J. R., \& Locke, E. A. (2004). The relation of entrepreneurial traits, skill, and motivation to subsequent venture growth. Journal of Applied Psychology, 89(4), 587-598.

Beehr, T. A., Drexler, J. A., Jr., \& Faulkner, S. (1997). Working in small family businesses: Empirical comparisons to non-family businesses. Journal of Organizational Behavior, 18(3), 297-312.

Bem, S. L. (1974). The measurement of psychological androgyny. Journal of Consulting and Clinical Psychology, 42(2), 155-162.

Bird, B. J. (1993). Demographic approaches to entrepreneurship: The role of experience and background. In J. A. Katz \& R. H. Brockhaus Sr. (Eds.), Advances in entrepreneurship, firm emergence and growth (pp. 11-48). Greenwich: JAI.

Birley, S. (1989). Female entrepreneurs: Are the really any different? Journal of Small Business Management, 27(1), 32-37.

Brenner, O. C., Pringle, C. D., \& Greenhaus, J. H. (1991). Perceived fulfillment of organizational employment versus entrepreneurship: Work values and career intentions of business college graduates. Journal of Small Business Management, 29(3), 62-74.

Brim, O. G. (1968). Adult socialization. In J. Clausen (Ed.), Socialization and society (pp. 183-226). Boston: Little Brown.

Brüderl, J., Preisendörfer, P., \& Ziegler, R. (1992). Survival chances of newly founded business organizations. American Sociological Review, 57(2), 227-242.

Brush, C. G., Carter, N. M., Gatewood, E. J., Greene, P. G., \& Hart, M. (Eds.). (2006). Growth-oriented women entrepreneurs and their businesses: A global perspective. Cheltenham, UK: Edward Elgar.

Caprana, G. V., \& Cervone, C. (2000). Personality: Determinants, dynamics, and potentials. New York: Cambridge University Press.

Carr, J. C., \& Sequeira, J. M. (2007). Prior family business exposure as intergenerational influence and entrepreneurial intent: A theory of planned behavior approach. Journal of Business Research, 60(10), 1090-1098.

Chell, E. (1985). The entrepreneurial personality: A few ghosts laid to rest? International Small Business Journal, 3(3), 43-54.

Chen, C. C., Greene, P. G., \& Crick, A. (1998). Does entrepreneurial self-efficacy distinguish entrepreneurs from managers? Journal of Business Venturing, 13(4), 295-316.

Chitsike, C. (2000). Culture as a barrier to rural women's entrepreneurship: Experience from Zimbabwe. Gender and Development, 8(1), 71-77. 
Cooper, A. C., \& Gimeno-Gascon, F. J. (1992). Entrepreneurs, processes of founding, and new firm performance. In D. Sexton \& J. Kasarda (Eds.), The state of art in entrepreneurship (pp. 301-340). Boston, MA: PWS Kent.

Costa, P. T., Jr., \& McCrae, R. R. (1992). Revised NEO personality inventory and NEO five factor inventory professional manual. Odessa, FL: Psychological Assessment Resources.

Costa, P. T., Jr., \& McCrae, R. R. (1997). Longitudinal stability of adult personality. In R. Hogan, J. Johnson, \& S. Briggs (Eds.), Handbook of personality psychology (pp. 269-290). San Diego: Academic.

Crant, J. M. (1996). The proactive personality scale as a predictor of entrepreneurial intentions. Journal of Small Business Management, 34(3), 42-49.

Das, T. K., \& Teng, S.-B. (2001). A risk perception model of alliance structuring. Journal of International Management, 7(1), 1-29.

Davidsson, P., \& Honig, B. (2003). The role of social and human capital among nascent entrepreneurs. Journal of Business Venturing, 18(3), 301-331.

Davis, P. S., \& Harveston, P. D. (1998). The influence of family on the family business succession process: A multi-generational perspective. Entrepreneurship Theory and Practice, 22(3), 31-53.

de Bruin, A., Brush, C. G., \& Welter, F. (2007). Advancing a framework for coherent research on women's entrepreneurship. Entrepreneurship Theory Practice, 31(3), 323-339.

De Witt, G., \& Van Winden, F. A. A. M. (1989). An empirical analysis of self-employment in the Netherlands. Small Business Economics, 1(4), 263-272.

Deaux, K., \& Kite, M. (1993). Gender stereotypes. In F. L. Denmark \& M. A. Paludi (Eds.), Psychology of women (pp. 107-139). Westport, CT: Greenwood.

Douglas, E., \& Shepherd, D. A. (2000). Entrepreneurship as a utility-maximizing response. Journal of Business Venturing, 15(3), 231-251.

Douglas, E., \& Shepherd, D. A. (2002). Self-employment as a career choice: Attitudes, entrepreneurial intentions, and utility maximization. Entrepreneurship Theory and Practice, 26(3), 81-90.

Dumas, C. (1989). Understanding of father-daughter and father-son dyads in family-owned businesses. Family Business Review, 2(1), 31-46.

Dumas, C. A. (1990). Preparing the new CEO: Managing the father-daughter succession process in family businesses. Family Business Review, 3(2), 169-181.

Dunn, T., \& Holtz-Eakin, D. (2000). Financial capital, human capital and the transition to self-employment: Evidence from intergenerational links. Journal of Labor Economics, 18(2), 282-305.

Dyer, Jr., Gibb, W., \& Handler, W. (1994). Entrepreneurship and family business: Exploring the connections. Entrepreneurship Theory and Practice, 19(1), 71-83.

Eddleston, K. A., Veiga, J. F., \& Powell, G. N. (2006). Explaining sex differences in managerial career preferences: The role of gender self-schema. Journal of Applied Psychology, 91(2), 437-445.

Engle, D. E., Mah, J. J., \& Sadri, G. (1997). An empirical comparison of entrepreneurs and employees: Implications of innovation. Creativity Research Journal, 10(1), 45-49.
Gartner, W. B. (1988). "Who is an entrepreneur?" is the wrong question. American Journal of Small Businesses, 12(4), 11-32.

Ghazali, A., Gosh, B. C., \& Tay, R. S. T. (1995). The determinants of self-employment choice among university graduates in Singapore. International Journal of Management, 12(1), 26-35.

Hair, J. F., Anderson, R. E., Tathum, R. L., \& Black, W. C. (1998). Multivariate data analysis with readings. New York: Macmillan.

Hofstede, G. (1980). Culture's consequences: International differences in work related values. Beverly Hills, CA: Sage.

Holland, J. L. (1985). Making vocational choices. Englewood Cliffs, NJ: Prentice Hall.

Hoy, F., \& Verser, T. G. (1994). Emerging business, emerging field: Entrepreneurship and the family firm. Entrepreneurship Theory and Practice, 19(1), 9-23.

Hunt, R. E., \& Adams, D. C. (1998). Entrepreneurial behavioral profiles and company performance: A cross-cultural comparison. International Journal of Commerce and Management, 8(2), 33-49.

Ibrahim, A. B., Soufani, K., \& Lam, J. (2001). A study of succession in a family firm. Family Business Review, 14(3), 245-258.

Kellermanns, F. W., \& Eddleston, K. A. (2004). Feuding families: When conflict does a family firm good. Entrepreneurship Theory and Practice, 28(3), 209-228.

Kepner, E. (1983). The family and the firm: A co-evolutionary perspective. Organizational Dynamics, 12(1), 57-70.

Kets de Vries, M. F. R. (1977). The entrepreneurial personality: A person at the crossroads. The Journal of Management Studies, 14(1), 34-57.

Kets de Vries, M. F. R. (1993). The dynamics of family controlled firms: The good and bad news. Organizational dynamics, 21(3), 59-71.

Kim, P., Aldrich, H. E., \& Keister, L. A. (2006). Access (not) denied: The impact of financial, human, and cultural capital on entrepreneurial entry in the United States. Small Business Economics, 27(1), 5-22.

Kimhi, A. (1997). Intergenerational succession in small family businesses: Borrowing contraints and optimal timing of succession. Small Business Economics, 9(4), 309-318.

Konrad, A. M., Ritchie, J. E., Lieb, P., \& Corrigall, E. (2000). Sex differences and similarities in job attitude preferences: A meta-analysis. Psychological Bulletin, 126(4), 593-641.

Korunka, C., Frank, H., Lueger, M., \& Mugler, J. (2003). The entrepreneurial personality in the context of resources, environment, and the startup process-a configurational approach. Entrepreneurship Theory and Practice, 28(1), $23-42$.

Krueger, N. F. Jr. (2000). The cognitive infrastructure of opportunity emergence. Entrepreneurship Theory and Practice, 24(3), 9-27.

Kuratko, D. F., \& Hodgetts, R. M. (2001). Entrepreneurship, a contemporary approach (5th ed.). Florida: Hartcourt College Publishers.

Landsberg, I. (1981). The succession conspiracy. Family Business Review, 1(2), 119-144.

Le Breton-Miller, I., Miller, D., \& Steier, L. P. (2004). Toward an integrative model of effective FOB succession. Entrepreneurship Theory and Practice, 28(4), 305-328. 
Liebowitz, B. (1986). Resolving conflict in the family-owned business. Consultation, 5(3), 191-205.

Lumpkin, T. G., \& Dess, G. G. (1996). Clarifying the entrepreneurial orientation construct and linking it to performance. Academy of Management Review, 21(1), 135-172.

Mancuso, J. R. (1974). What it takes to be an entrepreneur: A questionnaire approach. Journal of Small Business Management, 12(4), 16-22.

March, J. G., \& Shapira, Z. (1987). Managerial perspectives on risk and risk-taking. Management Science, 33(11), 14041418.

Marshall, J. P., Sorenson, R., Brigham, K., Wieling, E., Reifman, A., \& Wampler, R. S. (2006). The paradox for the family firm CEO: Owner age relationship to successionrelated processes and plans. Journal of Business Venturing, 21(3), 348-368.

Matthews, C. H., \& Moser, S. B. (1996). A longitudinal investigation of the impact of family background and gender on interest in small firm ownership. Journal of Small Business Management, 34(2), 29-43.

Menaghan, E. G., \& Parcel, T. L. (1995). Social source of change in children's home environment: The effects of parental occupational experience and family conditions. Journal of Marriage and the Family, 57(1), 69-84.

Minniti, M., Arenius, P., \& Langowitz, N. (2005). GEM report on women and entrepreneurship, Resource document. Babson College. Retrieved from http://www3.babson.edu/ CWL/research/GEM-Report-on-Women-and-Entrepreneur ship.cfm.

Morris, M. H., William, R. O., Allen, J. A., \& Avila, R. A. (1997). Correlates of success in family business transitions. Journal of Business Venturing, 12(5), 381-401.

Mueller, S. L. (2004). Gender gaps in potential for entrepreneurship across countries and cultures. Journal of Developmental Entrepreneurship, 9(3), 199-220.

Mueller, P. (2006). Entrepreneurship in the region: Breeding ground for nascent entrepreneurs? Small Business Economics, 27(1), 41-58.

Pervin, L. A., \& John, O. P. (1999). Handbook of personality: Theory and research. New York: Guilford.

Podsakoff, P. M., MacKenzie, S. B., Lee, J.-Y., \& Podsakoff, N. P. (2003). Common method bias in behavioral research: A critical review of the literature and recommended remedies. Journal of Applied Psychology, 88(5), 879-903.

Rauch, A., \& Frese, A. (2000). Psychological approaches to entrepreneurial success: A general model and an overview of findings. In C. L. Cooper \& I. T. Robertson (Eds.), International review of industrial and organizational psychology (pp. 100-135). Chichester Sussex: Wiley.

Rauch, A., \& Frese, M. (2007). Let's put the person back into entrepreneurship research: A meta-analysis on the relationship between business owners' personality and business creation and success. European Journal of Work and Organizational Psychology, 16(4), 353-385.

Rensink, R. A. (2000). Visual search for change: A probe into the nature of attentional processing. Visual Cognition, 7(1-3), 345-376.

Roccas, S., Sagiv, L., Schwartz, S. H., \& Knafo, A. (2002). The big five personality factors and personal values. Personality and Social Psychology Bulletin, 28(6), 789-801.
Rodriguez, S. N., Hildreth, G. J., \& Mancuso, J. (1999). The dynamics of families in business: How therapists can help in ways consultants don't. Contemporary Family Therapy, 21(4), 453-468.

Rosenthal, T. L., \& Bandura, A. (1978). Psychological modelling: Theory and practice. In S. L. Garfield \& A. E. Bergin (Eds.), Handbook of psychotherapy and behaviour change: An empirical analysis (pp. 621-658). New York: Wiley.

Rotter, J. B., Chance, J. E., \& Phares, E. J. (1972). Applications of a social learning theory of personality. New York: Holt, Rinehart \& Winston.

Ruble, D. N., \& Martin, C. L. (1998). Gender development. In W. Damon (Ed.), Handbook of child psychology (Vol. 3): Social, emotional, and personality development (pp. 9331016). New York: Wiley.

Russel, J., Jarvis, M., Roberts, C., Dwyer, D., \& Putwain, D. (2003). Angles on applied psychology. Tewkesbury: Nelson Thornes.

Schallberger, U., \& Venetz, M. (1999). Kurzversion des MRSInventars von Ostendorf (1990) zur Erfassung der fuenf "grossen" Persoenlichkeitsfaktoren. Zürich: Psychologisches Institut.

Schenk, R. (1998). Beurteilung des Unternehmenserfolges. In M. Frese (Hrsg.) (Ed.), Erfolgreiche Unternehmensgründer. Psychologische Analysen und praktische Anleitung für Unternehmer in Ost- und Westdeutschland (pp. 5982). Göttingen: Verlag für Angewandte Psychologie.

Scherer, R. F., Adams, J. S., Carley, S. S., \& Wiebe, F. A. (1989). Role model performance effects on development of entrepreneurial career preference. Entrepreneurship Theory and Practice, 13(3), 53-71.

Schmitt-Rodermund, E. (2004). Pathways to successful entrepreneurship: Parenting, personality, early entrepreneurial competence, and interests. Journal of Vocational Behavior, 65(3), 498-518.

Schmitt-Rodermund, E., \& Vondracek, F. W. (2002). Occupational dreams, choices and aspirations: Adolescents'entrepreneurial prospects and orientations. Journal of Adolescence, 25(1), 65-78.

Schröder, E., \& Schmitt-Rodermund, E. (2006). Crystallizing enterprising interests among adolescents through a career development program: The role of personality and family background. Journal of Vocational Behavior, 69(3), 494509.

Schulenberg, J. E., Vondracek, F. W., \& Crouter, A. C. (1984). The influence of the family on vocational development. Journal of Marriage and the Family, 46(1), 129-143.

Scott, M. G., \& Twomey, D. F. (1988). The long-term supply of entrepreneurs: Students' career aspirations in relation to entrepreneurship. Journal of Small Business Management, 26(4), 5-13.

Shane, S., Locke, E. A., \& Collins, C. J. (2003). Entrepreneurial motivation. Human Resource Management Review, 13(2), 257-279.

Sharma, P., \& Irving, P. G. (2005). Four bases of family business successor commitment: Antecedents and consequences. Entrepreneurship Theory and Practice, 29(1), 13-33.

Simon, M., Houghton, S. M., \& Aquino, K. (1999). Cognitive biases, risk perception, and venture formation: How 
individuals decide to start companies. Journal of Business Venturing, 15(2), 113-134.

Singh, G., \& DeNoble, A. (2003). Views on self-employment and personality: An exploratory study. Journal of Developmental Entrepreneurship, 8(3), 265-281.

Stavrou, E. T. (1999). Succession in family businesses: Exploring the effects of demographic factors on offspring intentions to join and take over the business. Journal of Small Business Management, 37(3), 43-61.

Stavrou, E. T., \& Swiercz, P. M. (1998). Securing the future of the family enterprise: A model of offspring intentions to join the business. Entrepreneurship Theory and Practice, 23(2), 19-39.

Sternberg, R., Bergmann, H., \& Lückgen, I. (2005) Global entrepreneurship monitor: Länderbericht Deutschland 2004. Köln: Wirtschafts- und Sozialgeographisches Institut, Universität zu Köln.

Stinchcombe, A. L. (1965). Organizations and social structure. Chicago: Rand McNally.
Tett, R. P., \& Burnett, D. D. (2003). A personality trait-based interactionist model of job performance. Journal of Applied Psychology, 88(3), 500-517.

Thurik, A. R., Carree, M. A., van Stel, A., \& Audretsch, D. B. (2008). Does self-employment reduce unemployment? Journal of Business Venturing, 23(6), 673-686.

Wang, C. K., \& Wong, P. (2004). Entrepreneurial interest of university students in Singapore. Technovation, 24(2), 163-172.

White, R. E., Thornhill, S., \& Hampson, E. (2007). A biosocial model of entrepreneurship: The combined effect of nurture and nature. Journal of Organizational Behavior, 28(4), 451-466.

Zhao, H., \& Seibert, S. E. (2006). The big five personality dimensions and entrepreneurial status: A meta-analytical review. Journal of Applied Psychology, 91(2), 259-271. 